\title{
Brunei Darussalam
}

National Cancer Institute

\section{Source}

National Cancer Institute. Brunei Darussalam. NCI Thesaurus. Code C16367.

A country in southeastern Asia, bordering the South China Sea and surrounded by Malaysia. 